\title{
Accumulation variability, density profiles and crystal growth trends in ITASE firn and ice cores from West Antarctica
}

\author{
Anthony J. GOW, ${ }^{1}$ Debra A. MEESE, ${ }^{1}$ Robert W. BIALAS ${ }^{2}$ \\ ${ }^{1}$ US Army Cold Regions Research and Engineering Laboratory, 72 Lyme Road, Hanover, NH 03755-1290, USA \\ E-mail: tgow@crrel.usace.army.mil \\ ${ }^{2}$ Dartmouth College, Hanover, NH 03755, USA
}

\begin{abstract}
Results of analyses of snow annual accumulation variability, density and crystal growth measurements in firn and ice cores recovered from the upper layers of the West Antarctic ice sheet during the US component of the International Trans-Antarctic Scientific Expedition (ITASE) are presented. Annual-layer structure was analyzed on the basis of the visible stratigraphy and electrical conductivity measurement record in each core. Annual accumulation varied appreciably between core sites and within cores at individual sites where undulating surface topography appears to be exerting a significant impact on the magnitude of snow deposition. All density profiles except one exhibited densification that was normal with respect to snow annual accumulation and $10 \mathrm{~m}$ firn temperatures. Snow annual accumulation was determined stratigraphically, and $10 \mathrm{~m}$ firn temperatures were either measured in the holes drilled for cores or inferred using elevation changes relative to Byrd Station, the $10 \mathrm{~m}$ temperature at Byrd Station and an assumed lapse rate. Measurements at the one exceptional location indicated that the firn had undergone extremely rapid densification to ice, with the transition to ice occurring at $35-36 \mathrm{~m}$ depth. Furthermore, thin-section measurements of grain-size show that the growth of crystals accelerated below the firn-ice transition. The behavior at this one site is attributed to localized deformation in the upper layers of firn and ice. Enhanced crystal growth was also observed at another site. At all other locations where grain-sizes were measured, the rates of crystal growth were in accord with age-temperature relationships observed by other researchers in Antarctica and Greenland. Profiles illustrating pore-crystal structure changes with increasing depth of burial are also presented.
\end{abstract}

\section{INTRODUCTION}

The purpose of this paper is to present results of major physical property and crystal structure measurements of firn and ice cores obtained during the United States International Trans-Antarctic Scientific Expedition (USITASE) oversnow traverse project in West Antarctica. We measured snow annual accumulation and evaluated age scales based on visual examination of the annual-layer stratigraphy at each site. Additional studies included density profile analyses, utilizing data obtained in the field, and measurements of crystal growth as a function of depth, age and temperature in firn and ice cores drilled at each site during three of the four legs of the USITASE traverse.

The major goal of ITASE, of which the US component is a part, is to establish the extent to which the modern atmospheric environment is preserved in the upper layers of the snow and ice of the Antarctic ice sheet. Specific objectives of ITASE include determination of the spatial variability of Antarctic climate, the environmental variability in Antarctica over the past 200 years, and changes in the mass balance over Antarctica (Mayewski and Goodwin, 1996). At a number of USITASE core-drilling sites where annual accumulation was low, drill depths were reached that exceeded 200 year old firn, extending the time-span over which changes in the mass balance of West Antarctica could be evaluated. On the other hand, at some sites where annual accumulation was higher, time-spans of the drilled core were appreciably less than 200 years.

The USITASE project involved a number of traverse routes or legs, along which shallow cores were drilled at intervals of approximately $100 \mathrm{~km}$ (Fig. 1). One of our first priorities was to visually examine the stratigraphy of the cores to delineate the annual-layer structure for dating purposes and to determine to as great a depth as possible the snowaccumulation variability over the full length of the strati-

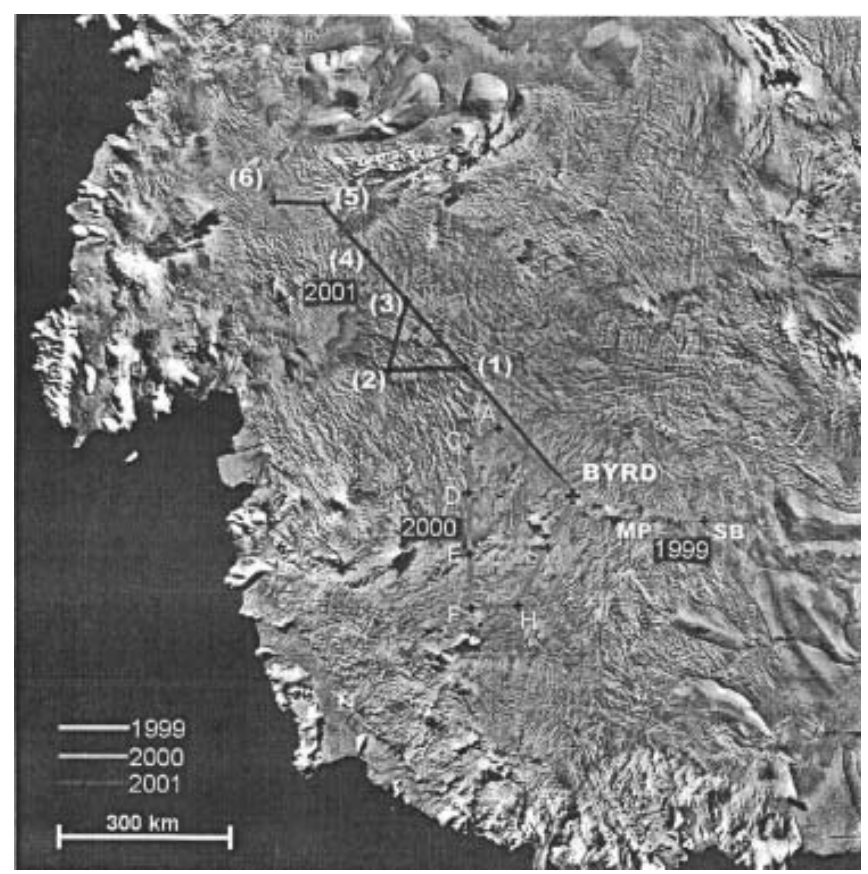

Fig. 1. USITASE route map of West Antarctica, with coring sites for 1999-2001 indicated. The map is based on a RADARSAT image of West Antarctica. 
Table 1. General dataset for USITASE 1999, 2000 and 2001 core sites

\begin{tabular}{|c|c|c|c|c|c|c|}
\hline Core site & $\begin{array}{c}\text { Core depth } \\
\mathrm{m}\end{array}$ & $\begin{array}{c}\text { Years of } \\
\text { accumulation }\end{array}$ & $\begin{array}{c}\text { Average } \\
\text { accumulation } \\
\text { mw.e. }\end{array}$ & $\begin{array}{c}\text { Elevation } \\
\mathrm{m}\end{array}$ & $\begin{array}{l}\text { Mean annual temp. } \\
{ }^{\circ} \mathrm{C}\end{array}$ & $\begin{array}{l}\text { Firn-ice transition } \\
\text { m }\end{array}$ \\
\hline MP & 48.80 & 214 & 0.147 & 1281 & $-26.9^{*}$ & 56 \\
\hline SB & 48.49 & 249 & 0.134 & 935 & -21.5 & 36 \\
\hline A & 105.26 & 460 & 0.172 & 1791 & $-29.5^{*}$ & 80 \\
\hline C & 61.09 & 148 & 0.263 & 1675 & $-28.9^{*}$ & 87 \\
\hline $\mathrm{D}$ & 60.13 & 172 & 0.226 & 1742 & $-29.2^{*}$ & 77 \\
\hline $\mathrm{E}$ & 58.17 & 223 & 0.173 & 1702 & $-29.0^{*}$ & 72 \\
\hline $\mathrm{F}$ & 59.68 & 340 & 0.119 & 1828 & $-29.7^{*}$ & 66 \\
\hline $\mathrm{H}$ & 60.27 & 368 & 0.110 & 1639 & $-28.7^{*}$ & 58 \\
\hline 1 & 63.61 & 358 & 0.118 & 1495 & $-28^{*}$ & 65 \\
\hline 1 & 72.92 & 194 & 0.253 & 1843 & -27.6 & 77 \\
\hline 2 & 70.93 & n.d. & n.d. & 1353 & -25.0 & 72 \\
\hline 3 & 70.83 & 142 & 0.330 & 1623 & -25.9 & 80 \\
\hline 4 & 68.12 & 156 & 0.294 & 1484 & -25.5 & 72 \\
\hline 5 & 114.33 & 239 & 0.363 & 1246 & -26.4 & 67 \\
\hline
\end{tabular}

*Estimated on the basis of a temperature lapse rate of $0.5^{\circ} \mathrm{C}(100 \mathrm{~m})^{-1}$ relative to the elevation $(1497 \mathrm{~m})$ and mean annual air temperature $\left(-28^{\circ} \mathrm{C}\right)$ at $\mathrm{Byrd}$ Station.

graphically dated cores. A second priority was to analyze depth-density profiles at each site. Accurate densities are needed to convert annual-layer thicknesses to ice or water equivalents. Additionally we were particularly interested in analyzing the dependence of depth-density profiles on both the rate of surface snow deposition and the in situ snow temperature. A third priority was to measure crystal size changes as a function of the depth, age and temperature of the firn; crystal growth is a strongly temperature-dependent process, and measurements to be made on USITASE cores collected between Byrd Station and the South Pole in 2002 will bridge a significant data gap for deep firn and ice in the mean annual temperature range between -31 and $-51^{\circ} \mathrm{C}$.

Together with density measurements, crystal structure examination of these cores will provide a valuable insight into the process by which air-rich firn is transformed into bubbly glacial ice. Knowledge of the path of crystalstructure changes as the firn densifies is also important in furthering our understanding of potentially significant changes in how chemical species, originally incorporated at the snow surface, are redistributed within the ice matrix or along crystal boundaries.

\section{ANALYTICAL TECHNIQUES}

\subsection{Stratigraphic examination}

General processing of cores was conducted at the US National Ice Core Laboratory (NICL), Denver, Colorado. At site 6 , coring was terminated prematurely at $18 \mathrm{~m}$ depth, so stratigraphic studies were not undertaken. Difficulties with interpreting visible stratigraphy were encountered in the top $20 \mathrm{~m}$ of core from site 5 and over the entire length of the drilled core from site 2 .

A light table was used to examine cores previously smoothed by microtoming during processing for electrical conductivity measurements (ECM). Annual layering was identified on the basis of coarse-grained summer layers and depth hoars overlying generally fine-grained snow deposited during the preceding winter. All light table observations were transferred at 1:1 scale to a core logbook containing
50 sheets of $1 \mathrm{~m}$ long graph paper. Annual layers were measured to the nearest millimeter and then combined with the appropriate density measurements to obtain water equivalents. Along with annual layering, such features as wind and ice crusts were also logged. These latter features are important for porosity and permeability studies (personal communication from M. Albert, 2003) and are of particular interest to ground-penetrating radar studies conducted along the research routes (e.g. reflection coefficients of 35-55 dB correspond to layers of 1-2 $\mathrm{mm}$ and small density contrasts) (personal communication from S. Arcone, 2003).

\subsection{Density measurements}

Density was measured in the field on all cores prior to general processing at NICL. Measurements were made on approximately $1 \mathrm{~m}$ long sections of core that generally consisted of just one or two pieces with ends that could be matched and readily fitted together. Core lengths were measured with a calibrated meter stick to the nearest $5 \mathrm{~mm}$. Core diameters were measured with digital calipers to $0.01 \mathrm{~mm}$, then weighed on a large triple-beam balance to $\pm 0.10 \mathrm{~g}$. The overall accuracy of the density measurements is estimated at $\pm 0.005 \mathrm{mg} \mathrm{m}^{-3}$.

\subsection{Crystal growth measurements}

Measurements of crystal size were based primarily on examinations of thin sections prepared at the Cold Regions Research and Engineering Laboratory (CRREL) on cores initially processed at NICL. Ten-millimeter-thick samples, spaced $2 \mathrm{~m}$ apart, were taken from each core and immersed in an organic filler (initially aniline but later dodecane) and frozen at $-20^{\circ} \mathrm{C}$ to solidify the permeable pore spaces between the firn grains. Frozen samples with glass slides attached were then sliced down to half the average grain diameter with a microtome. The finished thin sections were then photographed with a large bellows extension camera at $6 \times$ magnification. Crystal sizes (areas) were measured directly from photographic prints with a pocket comparator. As advocated by Gow (1969), crystal size was based on observations of the cross-sectional areas of the 50 largest 
crystals in the section (see Gow (1969) for full details of the thin-sectioning process and crystal size analysis). We concentrated our efforts on thin sections from below $10 \mathrm{~m}$, the depth at which temperatures in the firn become essentially isothermal. The mean grain-size of crystals in each section was determined, and growth rates for all sections in each core were obtained from a least-squares fit of the data points.

\subsection{Temperature measurements}

The only direct measurements of the average mean annual temperature were obtained down-hole with a thermistor at $10 \mathrm{~m}$ depth at sites 1-6. At each of these sites the thermistor was left in the hole overnight for about 8-10 hours. Because of the short duration of the measurements, the temperature data are estimated to be accurate to only about $0.3^{\circ} \mathrm{C}$. At site $\mathrm{SB}$, located near an automatic weather station, a mean annual surface air temperature of $-21.5^{\circ} \mathrm{C}$ has been reported (personal communication from M. Frey, 2003). Unfortunately, at all other sites, MP and A-I, drillhole temperatures were not measured. These were estimated instead on the basis of the elevation $(1497 \mathrm{~m})$ at Byrd Station, the $10 \mathrm{~m}$ temperature $\left(-28^{\circ} \mathrm{C}\right)$ at Byrd Station, and a temperature lapse rate of $0.5^{\circ} \mathrm{C}$ per $100 \mathrm{~m}$.

\section{RESULTS AND DISCUSSION}

\subsection{Snow-accumulation records}

Data pertaining to snow-accumulation records and related parameters obtained during the first three legs of the USITASE traverse are included in Table 1. Beginning with the two cores from 1999, site MP, located $100 \mathrm{~km}$ from Byrd Station, yielded 214 years of accumulation, giving an average yearly accumulation of $0.147 \mathrm{~m}$ w.e.

At site SB, located $200 \mathrm{~km}$ from Byrd Station, 249 years of accumulation yielded an average annual accumulation of $0.134 \mathrm{~m}$ w.e. The snow and firn in this core has undergone much more rapid densification with depth than would have been inferred from the measured annual accumulation and the mean annual surface air temperature. (The reasons for this are treated more thoroughly in later sections focusing on the densification and crystal growth processes in snow.) Also, ECM, together with results based on visual stratigraphy, yielded excellent agreement between the two dating techniques, which correlated within $2 \%$ for each core by the time the bottom of each hole was reached. Seven cores obtained in 2000 were later analyzed and age-dated from sites A-I.

Much variability in annual accumulation was observed between sites, as indicated in Table 1, and also within cores along this traverse route. In several cores, especially near the southern end of the traverse, including sites $\mathrm{F}, \mathrm{H}$ and $\mathrm{I}$, the stratigraphic and ECM analyses were remarkably similar and matched very well on independent analysis. At all three sites the two dating techniques correlated within 3\% for the three cores over their 340-368 year record of snow accumulation at the bottom of each drillhole. However, cores from sites C-E with a much higher annual accumulation proved much more difficult to analyze, both stratigraphically and with the ECM instrument. As results clearly show in Table 1, snow accumulation along the route of sites 1-5 varied from moderate to high, with average values ranging from $0.212 \mathrm{~m}$ w.e. at site 2 to $0.363 \mathrm{~m}$ w.e. at site 5 .
Table 2. Annual accumulation variability at selected USITASE coring sites based on $10 \mathrm{~m}$ increment averages

\begin{tabular}{|c|c|c|c|}
\hline \multirow[b]{2}{*}{ Core site } & \multicolumn{3}{|c|}{ Accumulation } \\
\hline & $\begin{array}{l}\text { Lowest } \\
\text { mw.e. }\end{array}$ & $\begin{array}{l}\text { Highest } \\
\text { m w.e. }\end{array}$ & $\begin{array}{c}\text { Average } \\
\text { m w.e. }\end{array}$ \\
\hline MP & 0.136 & 0.166 & 0.147 \\
\hline $\mathrm{SB}$ & 0.110 & 0.143 & 0.134 \\
\hline $\mathrm{H}$ & 0.100 & 0.130 & 0.110 \\
\hline I & 0.104 & 0.135 & 0.118 \\
\hline 1 & 0.232 & 0.267 & 0.253 \\
\hline 3 & 0.296 & 0.348 & 0.330 \\
\hline 4 & 0.212 & 0.379 & 0.294 \\
\hline
\end{tabular}

Appreciable variability in annual accumulation within cores is a characteristic feature at many sites. This variability applied particularly to accumulation averaged over $10 \mathrm{~m}$ increments, beginning at $0-10 \mathrm{~m}$ and continuing to the bottom of each core. The results presented in Table 2 show the highest and lowest $10 \mathrm{~m}$ incremental values of annual accumulation at several selected sites. These values were obtained by calculating the ice equivalent in each $10 \mathrm{~m}$ increment and dividing by the number of annual layers in that increment. Rather than representing responses to shortterm fluctuations in climate, much of the variability indicated in Table 2 is interpreted as reflecting the existence, and the effect on snow accumulation, of the large and small surface undulations observed along much of the route of the USITASE. Such undulations ranged in wavelength from a few to $20 \mathrm{~km}$, with amplitudes of up to $20 \mathrm{~m}$ and more.

Undulating surface topography is known to systematically influence snow accumulation in both West and East Antarctica (Black and Budd, 1964; Gow and Rowland, 1965; Whillans, 1975; Richardson and others, 1997; Richardson and Holmlund, 1999; Van der Veen and others, 1999; Holmlund and others, 2000). At Byrd Station, for example, long-term stake-line measurements have shown that surface depressions accumulate $30-50 \%$ more snow than the exposed crests of surface undulations (Gow and others, 1972). These surface undulations appear in many cases to be directly related to irregularities in the bedrock underlying the Antarctic ice sheet. In this case, these undulations could be creating waves of accumulation that actively migrate across the surface of the ice sheet. For example, Black and Budd (1964) have estimated a wave migration rate of $25 \mathrm{~m} \mathrm{a}^{-1}$ in Wilkes Land, and Whillans (1972) estimated a migration rate of $20 \mathrm{~m} \mathrm{a}^{-1}$ in the general vicinity of Byrd Station. As alluded to above, such surface-modulated variability in accumulation, when observed in vertically drilled cores, could mistakenly be attributed to short-term fluctuations in climate (Van der Veen and others, 1999).

The effect of topographic forcing on accumulation variability and its implications for ice-core interpretation are being actively investigated (Hamilton, 2004), especially in regard to ground-penetrating radar results (Richardson and others, 1997; Richardson and Holmlund, 1999; Arcone and others, 2004; Spikes and others, 2004).

\subsection{Density profiles}

At all sites where we examined core in detail, melting was found to be negligible to non-existent. Under these dry snow 


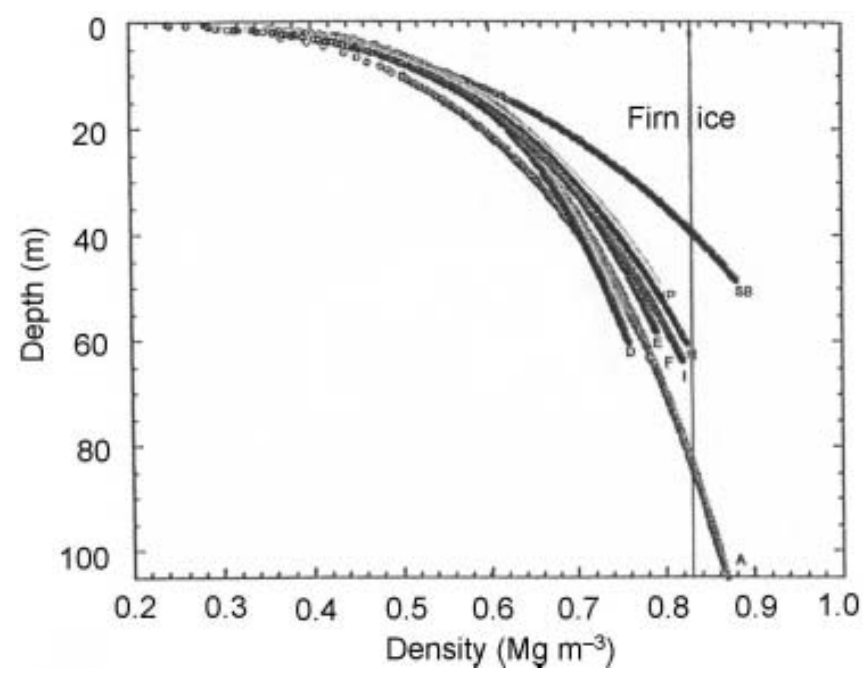

Fig. 2. Smoothed depth-density profiles for cores drilled during the 1999 and 2000 USITASE.

conditions the process of densification will be the same at all sites; however, the rate at which snow densifies with depth is determined by the temperature of the snow and the speed with which it is deposited. Accordingly, the higher the temperature of the snow and the smaller the annual accumulation, the faster the snow will densify and vice versa. Depth-density profiles measured during the USITASE are presented as smoothed curves in Figures 2 and 3. For the most part, the profiles were consistent with the stratigraphically determined annual accumulation and temperatures measured at $10 \mathrm{~m}$ depth in drillholes or those inferred using drill-site elevations relative to the elevation at Byrd Station, the mean annual surface air temperature at Byrd Station, and a lapse rate of $0.5^{\circ} \mathrm{C}(100 \mathrm{~m})^{-1}$.

The density profile at site MP almost exactly duplicated the profile at Old Byrd Station (Gow 1968), where the annual accumulation is slightly higher $(0.150 \mathrm{~m}$ w.e. compared to $0.147 \mathrm{~m}$ w.e. at site MP) but the $10 \mathrm{~m}$ temperature is slightly lower $\left(-28^{\circ} \mathrm{C}\right.$ compared to $-26.9^{\circ} \mathrm{C}$ at site MP). These factors are mutually offsetting, leading to nearly identical depth-density profiles at the two locations.

At site SB, however, the firn has undergone extremely rapid densification to ice, much more rapid than would be inferred from the annual accumulation ( $0.134 \mathrm{mw}$ w.e) and the mean annual temperature $\left(-21.5^{\circ} \mathrm{C}\right)$. The transition from firn to ice, occurring at $36 \mathrm{~m}$, is among the shallowest observed anywhere in the dry-snow facies of Antarctica. This transition, which occurs at a density of $0.83 \mathrm{Mg} \mathrm{m}^{-3}$, is only 2-3 $\mathrm{m}$ deeper than that observed at Upstream B (UpB) by Alley and Bentley (1988), who attribute the anomalously rapid densification at UpB to large longitudinal stresses related to the location of UpB within the upper confines of Ice Stream B. Accelerated densification of firn was also observed at Little America $V$ by Gow (1968), who also attributed this behavior to large horizontal stresses acting in
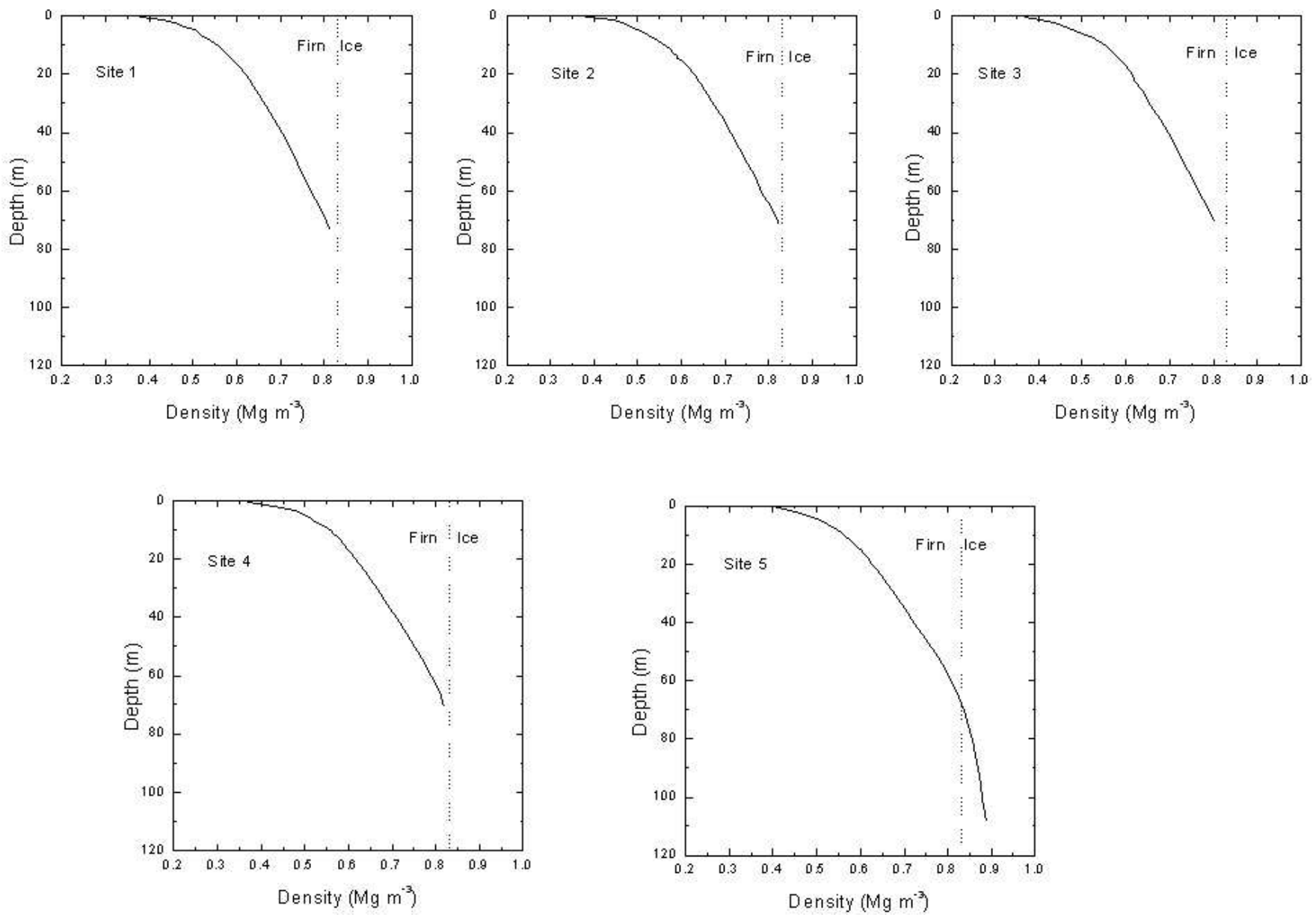

Fig. 3. Smoothed depth-density curves for cores collected during the 2001 USITASE. The profile for site 6 is not included because of premature termination of core drilling. 
addition to the overburden pressure. A similar situation may apply at site SB, which happens to be located close to a catchment basin of Bindschadler Ice Stream (former Ice Stream D). In contrast to the situation at site SB, the firn-ice transition at site $C$ is not encountered until $87 \mathrm{~m}$ depth, which would place it among the deepest transitions in West Antarctica.

Of the 14 cores analyzed from along the route of the three USITASE traverses, eight had firn-ice transition depths that exceeded $70 \mathrm{~m}$. The fact that all eight sites were located in areas of moderately high to high snow accumulation would indicate that this, rather than in situ firn temperature, has been a dominant factor in determining firn-ice transition depths. This is because the age of the firn as a function of depth is itself determined by the rate at which snow is deposited at the surface. This means that there is less time at any given depth (and in situ temperature) for densification to occur, thereby extending the depth at which firn transforms into ice at the larger annual accumulation.

\subsection{Crystal growth}

In addition to densification, the overall process of the transformation of snow and firn to ice is accompanied by recrystallization. A major consequence of recrystallization of firn is the increase in size of the crystals with increasing age and depth of burial.

Stephenson (1967) and Gow (1969) independently established that the size of crystals in polar firn increased linearly with the age of the firn according to the expression:

$$
D^{2}=D_{0}^{2}+\mathrm{k} t,
$$

where $D$ is the mean crystal cross-sectional area (in $\mathrm{mm}$ ) at time $t$ (years) and $D_{0}$ is the mean crystal cross-section extrapolated to zero age. This relationship is essentially identical to that established for isothermal grain growth in metals (Burke and Turnbull, 1952), where the immediate driving force of growth is generally attributed to the interfacial free energy of the crystal boundaries (Cole and others, 1954). Stephenson (1967) and Gow (1969) also demonstrated that the temperature dependence of the crystal growth rate $\left(\mathrm{k}=\left(D_{2}-D_{0}^{2}\right) / t\right)$ could be expressed according to the Arrhenius equation:

$$
\mathrm{k}=\mathrm{k}_{0} \exp (-E / R T),
$$

where $\mathrm{k}_{0}$ is a constant, $E$ and $R$ are the activation energy and gas constant, respectively, and $T$ is the firn temperature (essentially constant below $10 \mathrm{~m}$ ) in Kelvin.

Plots of firn crystal size vs age for cores drilled during the 1999, 2000 and 2001 USITASE traverses are given in Figures 4 and 5 . Both figures show good linear fits of firn crystal size vs age. At a number of locations this linear growth of crystals with time extends for some distance below the firn-ice transition. This region of linear increase in the size of crystals with time is referred to as the normal grain-growth regime (Alley, 1992). It is now known to persist to considerable depth in both the Antarctic and Greenland ice sheets (Gow and Williamson, 1976; Herron and Langway, 1982; Woods, 1994; Thorsteinsson and others, 1997). Age was determined from annual-layer counts based on examination of the visual stratigraphy.

An inspection of Figure 4 shows a good linear fit to the crystal-size data vs age for site MP. However, at site SB the crystal-growth vs age relationship is not so simple. It would appear that two curves of vastly different slope can be drawn

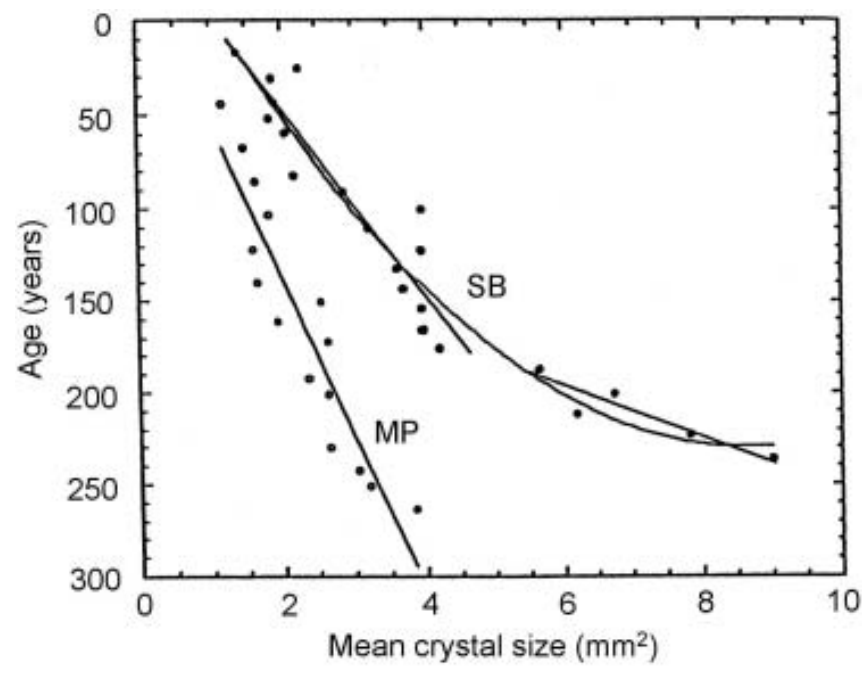

Fig. 4. Plots of crystal size variation vs age of firn and ice for cores from sites collected during the 1999 USITASE. Note the rapid increase in the rate of growth of crystals in ice at site SB.

through the data points, one encompassing growth in the firn and the other incorporating data points that lie entirely in ice. The rapid increase in the size of crystals observed below the firn-ice transition at site SB is not compatible with either the mean annual temperature or age characteristics of the ice at this location. As in the case of the unusually rapid rate of densification at site $\mathrm{SB}$, it is suspected that highly localized stresses, related to its close proximity to Bindschadler Ice Stream, have also contributed to the accelerated crystal growth observed in ice at site SB.

A sudden increase in the size of crystals is also observed beginning at around the firn-ice transition at site 5 . However, firn densification at this site seems normal with respect to the measured annual accumulation and $10 \mathrm{~m}$ temperature. The question of why the crystal size should suddenly increase in ice at site 5 remains unresolved. It is worth noting, however, that site 5 is located in a highaccumulation area of West Antarctica. Li and Jacka (1999), in their study of crystal growth rates in cores from highaccumulation sites in East Antarctica, also observed sudden increases in the growth rate of crystals in ice below the firnice transition. They attributed this behavior to deformation induced by high accumulation, a process in which normal grain growth is replaced by dynamic recrystallization of the ice and associated rapid increases in crystal size. At all other USITASE sites, reasonably linear fits of firn crystal-size data vs age were obtained.

Figure 6 includes a plot of crystal growth rates vs 1000/T for cores from the USITASE sites. The increased rate of crystal growth in ice at both site SB and site 5 is clearly indicated by their elevated positions with respect to the remaining USITASE data points, which were closely clustered about a line, the position and slope of which were determined by Paterson (1994) from regression analysis of the circled data points. These circled data points were obtained from studies made earlier in Greenland and Antarctica and were used by Paterson to determine an activation energy of $42.4 \mathrm{~kJ} \mathrm{~mole}^{-1}$ for grain boundary selfdiffusion. This is an appropriate value, since the driving force of crystal growth in firn can be attributed to the interfacial free energy of the grain boundaries. Earlier, 

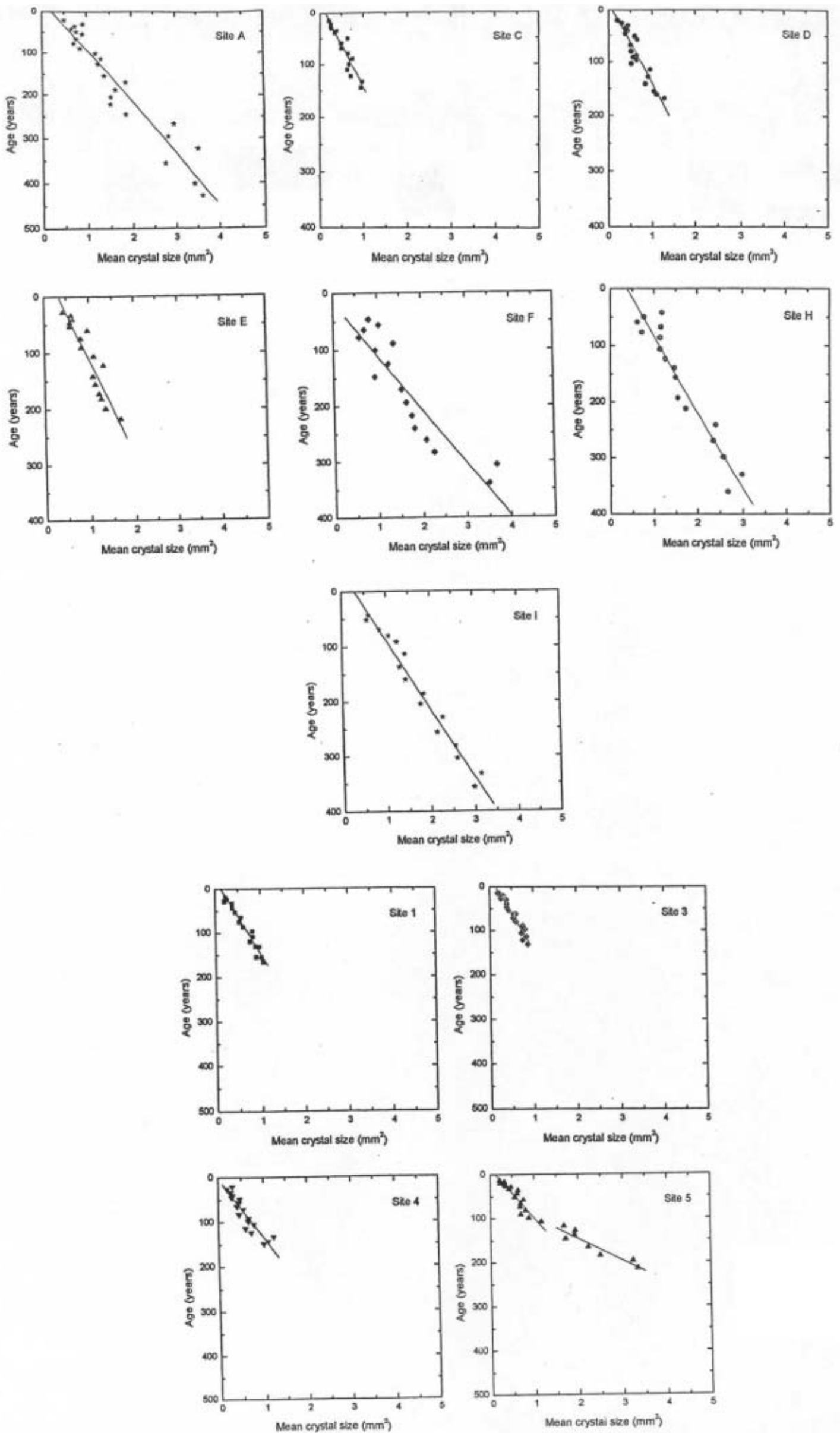

Fig. 5. Plots of crystal size variation vs age of firn and ice for cores drilled during the 2000 and 2001 USITASE. Note the sudden increase in the rate of growth of crystals in ice at site 5. Thin sections were not prepared for site 6 core because of premature termination of drilling. Crystal size measurements are not plotted for site 2 because of unresolved difficulties with the dating of this core. 


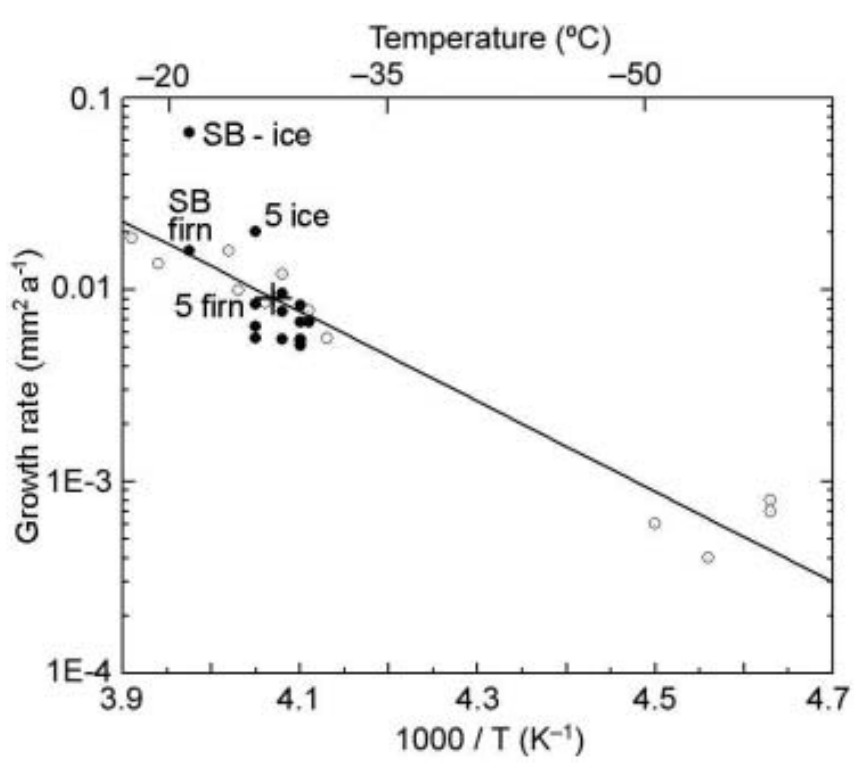

Fig. 6. Temperature dependence of crystal growth rates in firn and ice cores collected during the 1999, 2000 and 2001 USITASE. The diagram on which the USITASE data are plotted was adapted from Paterson (1994).

Gow (1971), using a mix of crystal growth rates from five locations in Greenland and Antarctica, obtained an activation energy for self-diffusion of $44.5 \mathrm{~kJ} \mathrm{~mole}^{-1}$, slightly higher than the value calculated by Paterson. Additionally, Paterson examined results of firn crystal growth-rate studies made by Nishimura and Maeno (1988) and Qin and others (1988), and determined an activation energy of $42.3 \mathrm{KJ} \mathrm{mole}^{-1}$, essentially the same as that obtained by Paterson (1994).

Gow's (1971) and Paterson's (1994) activation energies are appreciably smaller than the generally accepted value for volume self-diffusion in ice (about $60 \mathrm{~kJ} \mathrm{~mole}^{-1}$ ). This approximately $30 \%$ difference in activation energies for volume self-diffusion and grain-boundary self-diffusion can probably be attributed to the fact that stresses in firn, arising from the build-up of the snow load, cause crystals to deform, which releases energy that would supplement the surface energy stored in the crystal boundaries. This additional source of energy would reduce the apparent activation energy to something less than that of volume self-diffusion. A similar $30 \%$ difference in the activation energies between volume self-diffusion and grain-boundary self-diffusion has also been measured in metals (Cole and others, 1954).

A plot of crystal size vs age for all thin sections of USITASE cores, excluding sites 2 and 6 and those measurements of enhanced crystal growth in ice at sites SB and 5, is shown in Figure 7. The slope of the straight line determined by regression analysis gives a composite growth rate of $0.009 \mathrm{~mm}^{2} \mathrm{a}^{-1}$, indicated by a cross in Figure 6 .

The clustering of data points about the straight line in Figure 6 is to be expected, given the fairly narrow range of temperatures at the USITASE sites where crystal sizes were measured. However, in conjunction with the many measurements that have now been made in Greenland and Antarctica, the new USITASE datasets serve to confirm the very strong dependence of crystal growth rates on temperature in the upper layers of firn and ice in polar ice sheets.

The changes in texture demonstrated in Figure 8 are involved primarily with changes in the sizes and shapes of

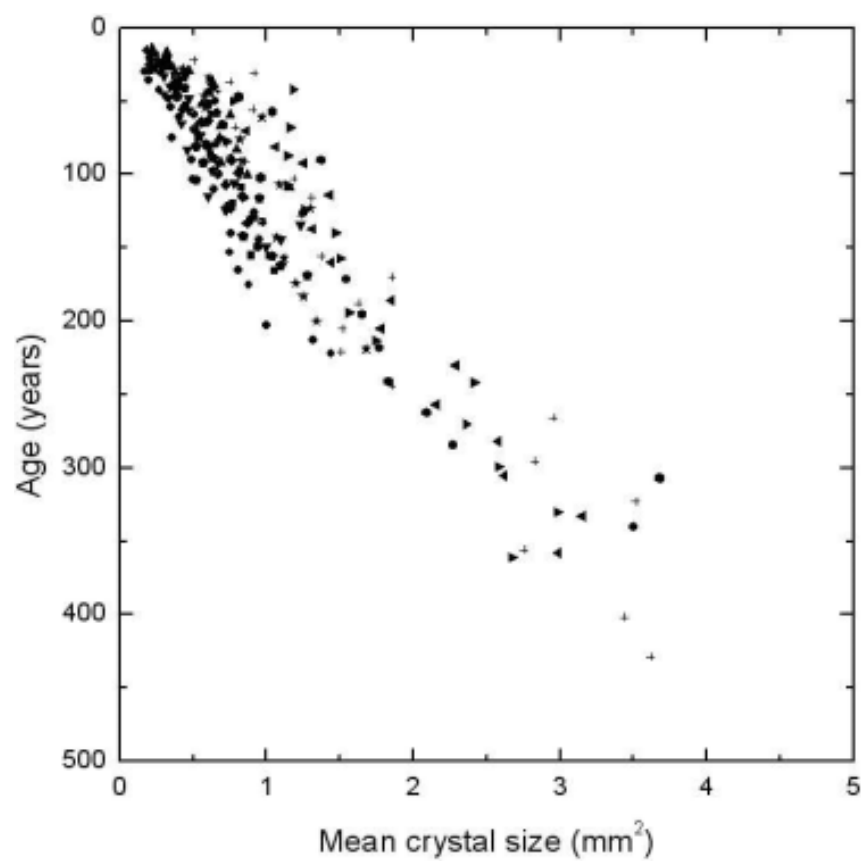

Fig. 7. Plot of crystal size data vs age for USITASE cores excluding those measurements of enhanced crystal growth in ice at sites SB and 5 . The slope of the straight line determined by regression analysis gives a composite growth rate of $0.009 \mathrm{~mm} \mathrm{a}^{-1}$, indicated by a cross in Figure 6 .

crystals, growth of intergranular bonds, and changes in the size and shape of pores associated with the gradual elimination of pore spaces (densification) as the depth of burial increases. By $10 \mathrm{~m}$ depth the bonding between grains and crystals becomes so strong that rupture of intergranular bonds to facilitate closer packing of the grains is no longer possible. Any further modification of firn texture now occurs as a result of visco-plastic deformation of the grains. Deformation of grains in contact with one another causes material at the more highly stressed grain boundaries to migrate into the intervening pore space, thereby changing the shape of the pores and decreasing the permeability and porosity of the firn.

Ultimately the process of firn densification is terminated when the permeability reduces to zero and porosity is reduced to around $10 \%$. Pores now consist of bubbles isolated within the ice crystal matrix; this condition constitutes the firn-ice transition. Bubbles are confined mainly to the intersections of crystals; with increasing depth below the firn-ice transition, bubbles become enclosed in crystals as the crystals grow larger. Below $10 \mathrm{~m}$ all stages of this firn-to-ice transformation are displayed in the porecrystal structure profiles presented in Figure 8 . The much smaller size of firn crystals at site D compared to those at comparable depths at site $\mathrm{A}$ is due to age differences, the age of the firn at site $D$ being much less at comparable depths than at site A. Note, however, that the time rate of growth of crystals at sites $A$ and $D$ is very similar because growth rates are strongly dependent on the in situ firn temperatures, which also are very similar at sites A and D.

\section{CONCLUSIONS}

Annual accumulation, determined on the basis of diagnostic seasonal signals in the visual stratigraphy measurements and 

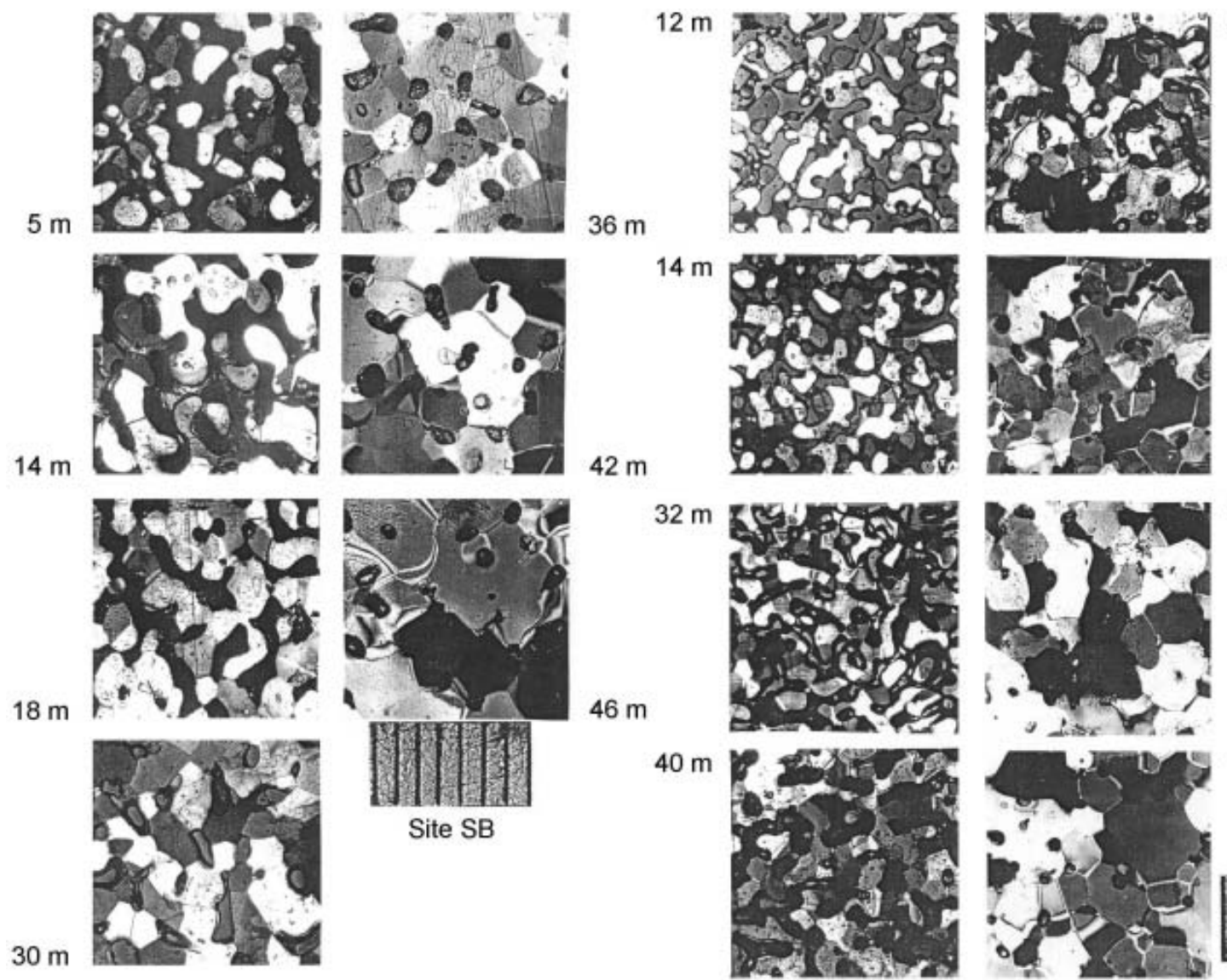

$52 \mathrm{~m}$
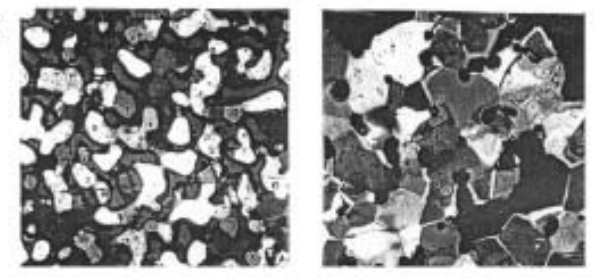

$75 \mathrm{~m}$
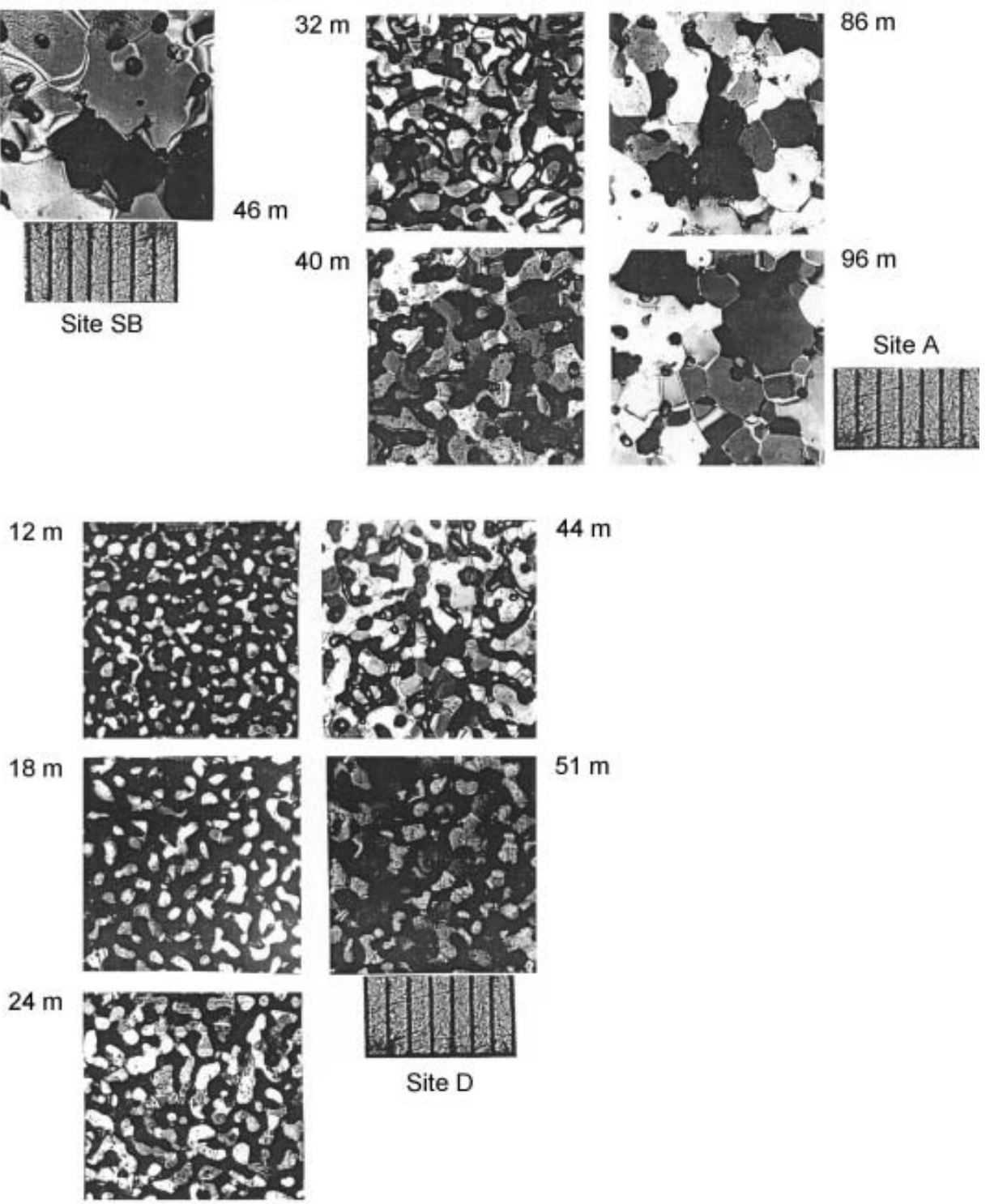

Site D

$36 \mathrm{~m}$

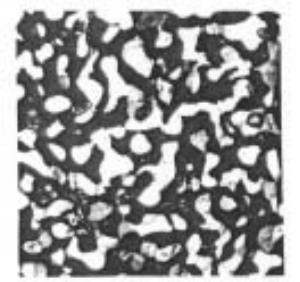

Fig. 8. Thin-section structure photographs illustrating pore-crystal relationships in firn and ice at the USITASE sites SB, A and D. The photographs were taken between crossed polarizers to reveal the crystalline nature of the grains. The smallest-scale subdivisions measure $1 \mathrm{~mm}$. In shallow firn, pores appear as worm-like inclusions before transforming into sieve-like inclusions in mid-level and deeper firn. In ice, pores appear as rounded inclusions or bubbles located mainly at the intersections of crystals or within the crystals. 
ECM, ranges from 0.11 mw.e. near Byrd Station in the interior of West Antarctica to $0.363 \mathrm{~m}$ w.e. near the coast. Except for a single anomalously warm location, this large variability in annual accumulation occurred over a mean annual surface temperature range of $<5^{\circ} \mathrm{C}$. Appreciable variability in accumulation occurred not only between traverse sites but within cores retrieved at individual sites, where undulating surface topography observed over much of the USITASE traverse route appears to be exerting a significant impact on the magnitude of snow deposition.

Density profiles for the most part were found to be consistent with what would be expected from the stratigraphically measured annual accumulation and the measured in situ firn temperatures and from temperatures inferred from site elevation changes relative to Byrd Station. Measurements at a single location indicated an anomalously high rate of densification, leading to a firn-ice transition at 35-36 m depth. This and an accelerated growth of crystals below the firn-ice transition are both attributed to localized stress, believed linked to the close proximity of this site to the catchment basin of an ice stream. At a number of sites the firn-ice transitions exceeded $70 \mathrm{~m}$, and at one location the transition occurred at $87 \mathrm{~m}$, among the deepest yet observed in West Antarctica.

Measurements of crystal size on 13 cores from 15 USITASE sites confirmed earlier research of a strong linear relationship between crystal cross-sectional areas and their ages. A strong dependence on temperature of the crystal growth rates was also demonstrated, further confirming results of earlier studies in Greenland and Antarctica.

\section{ACKNOWLEDGEMENTS}

The authors are indebted to the Office of Polar Programs, US National Science Foundation, for financial support. They also thank their colleagues for access to many measurements they made in the course of fieldwork.

\section{REFERENCES}

Alley, R. B. 1992. Flow-law hypotheses for ice-sheet modeling. J. Glaciol., 38(129), 245-256.

Alley, R. B. and C. R. Bentley. 1988. Ice-core analysis on the Siple Coast of West Antarctica. Ann. Glaciol., 11, 1-7.

Arcone, S. A., V. B. Spikes, G. S. Hamilton and P. A. Mayewski. 2004. Stratigraphic continuity in $400 \mathrm{MHz}$ short-pulse radar profiles of firn in West Antarctica. Ann. Glaciol., 39 (see paper in this volume).

Black, H.P. and W. Budd. 1964. Accumulation in the region of Wilkes, Wilkes Land, Antarctica. J. Glaciol., 5(37), 3-15.

Burke, J.E. and D. Turnbull. 1952. Recrystallization and grain growth. Prog. Metal Phys., 3, 220-292.

Cole, D. G., P. Feltham and E. Gillam. 1954. On the mechanism of grain growth in metals with special reference to steel. Proc. $R$. Soc. London, Ser. B, 67, 131-137.

Gow, A.J. 1968. Deep core studies of the accumulation and densification of snow at Byrd Station and Little America V, Antarctica. CRREL Res. Rep. 197.

Gow, A.J. 1969. On the rates of growth of grains and crystals in South Polar firn. J. Glaciol., 8(53), 241-252.

Gow, A.J. 1971. Depth-time-temperature relationships of ice crystal growth in polar glaciers. CRREL Res. Rep. 300.

Gow, A.J. and R. Rowland. 1965. On the relationship of snow accumulation to surface topography at 'Byrd Station', Antarctica. J. Glaciol., 5(42), 843-847.

Gow, A. J. and T. Williamson. 1976. Rheological implications of the internal structure and crystal fabrics of the West Antarctic ice sheet as revealed by deep core drilling at Byrd Station. Geol. Soc. Am. Bull., 87(12), 1665-1677.

Gow, A. J., F. de Blander, G. Crozaz and E. Picciotto. 1972. Snow accumulation at 'Byrd' station, Antarctica. J. Glaciol., 11(61), 59-64.

Hamilton, G.S. 2004. Topographic control of regional accumulation-rate variability at South Pole and implications for ice-core interpretation. Ann. Glaciol., 39 (see paper in this volume).

Herron, S. L. and C. C. Langway, Jr. 1982. A comparison of ice fabrics and textures at Camp Century, Greenland and Byrd Station, Antarctica. Ann. Glaciol., 3, 118-124.

Holmlund, P. and 15 others. 2000. Spatial gradients in snow layering and $10 \mathrm{~m}$ temperatures at two EPICA-Dronning Maud Land (Antarctica) pre-site-survey drill sites. Ann. Glaciol., 30, 13-19.

Li Jun and T.H. Jacka. 1999. Crystal-growth rates in firn and shallow ice at high-accumulation sites. Ann. Glaciol., 29, 169-175.

Mayewski, P.A. and I.D. Goodwin. 1996. International TransAntarctic Scientific Expedition (ITASE). '200 years of past Antarctic climate and environmental change.' Science and implementation plan, 1996. Report from the ITASE Workshop, Cambridge, United Kingdom, 2-3 August, 1996. Durham, NH, University of New Hampshire. International Geosphere-Biosphere Programme, Scientific Committee on Antarctic Research. (PAGES Workshop Report 97-1.)

Nishimura, H. and N. Maeno. 1988. Characteristic growth processes of ice crystals on the Antarctic ice sheet. Ann. Glaciol., 11, 104-108.

Paterson, W.S.B. 1994. The physics of glaciers. Third edition. Oxford, etc., Elsevier.

Qin Dahe, N.W. Young and R.J. Thwaites. 1988. Growth rate of crystals within the surface-snow/firn layer in Wilkes Land, East Antarctica. Ann. Glaciol., 11, 121-125.

Richardson, C. and P. Holmlund. 1999. Spatial variability at shallow snow-layer depths in central Dronning Maud Land, East Antarctica. Ann. Glaciol., 29, 10-16.

Richardson, C., E. Aarholt, S.-E. Hamran, P. Holmlund and E. Isaksson. 1997. Spatial distribution of snow in western Dronning Maud Land, East Antarctica, mapped by a groundbased snow radar. J. Geophys. Res., 102(B9), 20,343-20,353.

Spikes, V.B., G.S. Hamilton, S. A. Arcone, S. Kaspari and P. Mayewski. 2004. Variability in accumulation rates from GPR profiling on the West Antarctic plateau. Ann. Glaciol., 39 (see paper in this volume).

Stephenson, P. J. 1967. Some considerations of snow metamorphism in the Antarctic ice sheet in the light of ice crystal studies. In Ōura, H., ed. Physics of snow and ice. Vol. 1, Part 2. Sapporo, Hokkaido University. Institute of Low Temperature Science, 725-740.

Thorsteinsson, Th., J. Kipfstuhl and H. Miller. 1997. Textures and fabrics in the GRIP ice core. J. Geophys. Res., 102(C12), 26,583-26,599.

Van der Veen, C. J., E. Mosley-Thompson, A. Gow and B. G. Mark. 1999. Accumulation at South Pole: comparison of two 900-year records. J. Geophys. Res., 104(D24), 31,067-31,076.

Whillans, I.M. 1972. Ice-sheet dynamics near Byrd Station. Antarct. J. US, 7(4), 111.

Whillans, I. M. 1975. Effect of inversion winds on topographic detail and mass balance on inland ice sheets. J. Glaciol., 14(70), 85-90.

Woods, G. A. 1994. Grain growth behaviour of the GISP2 ice core from central Greenland. (B.Sc. thesis, The Pennsylvania State University.) 